\title{
Barriers in using computer related teaching aids among faculty members in a newly established medical college - a Cross Sectional Study
}

\author{
Bishwalata Rajkumari*
}

\section{Bishwalata Rajkumari*}

Department of Community Medicine Jawaharlal Nehru Institute of Medical Sciences, Porompat Imphal, Manipur, INDIA.

\section{Correspondence}

Dr Bishwalata Rajkumari*, MD

Associate Professor

Department of Community Medicine

Jawaharlal Nehru Institute of Medical

Sciences, Porompat

Imphal, Manipur- 795010, INDIA.

Ph.no: +919436038764

Email: dr.bishwalata@rediffmail.com

\section{Histor}

- Submission Date: 05-02-2016

- Review completed: 22-06-2016

- Accepted Date: 30-08-2016.

DOI : 10.5530/ijmedph.2016.4.5

Article Available online

http://www.ijmedph.org/v6/i4

\section{Copyright}

(C) 2016 Phcog.Net. This is an openaccess article distributed under the terms of the Creative Commons Attribution 4.0 International license.

\begin{abstract}
Introduction: Teaching aids are tools which make teaching easier \& learning more effective and enjoyable. Newer aids like computers and LCD (Liquid Crystal Display) projectors have been widely adopted in education system to make teaching process more effective. The study plans to assess the knowledge, attitude \& practice of newer form of teaching aids \& identify the barriers to use among faculty members of a newly established medical college. Methods: A cross sectional study was conducted using both quantitative and qualitative methods among faculty members of Jawaharlal Nehru Institute of Medical Sciences, Imphal during September 2014 to Feb 2015 using a self-administered semi-structured questionnaire along with interview guides for in-depth interview. Approval from the Institutional Ethics committee was obtained. Descriptive statistics and chi-square test were performed and qualitative data was grouped into domains and coded responses were analysed in consonance with stated objectives. Results: Out of the 88 respondents 55 (62.5\%) were males and $23(26.1 \%)$ faculty were above 65 years of age. Around $13.6 \%$ of the respondents said they do not have basic knowledge of computer. 'Feel too old to learn', 7 (58.3\%) was main reason for not having knowledge of computers. Majority of the respondents, 78 (88.6\%) used computer in taking theory/lecture class. One-third of the faculty, 33 (37.5\%) said they need help/assistance in preparing power-point presentations and almost two third of them, $53(60.2 \%)$ have undergone Basic training course in MET (Medical Education Technology). Senior faculty expressed that 'Older generation thinks old is gold and are more habituated to older teaching methods'. Conclusion: Old age and lack of computer knowledge were the major barriers identified. Compulsory training in basic course on MET along with faculty development programs with short course on computer is the need of the hour.
\end{abstract}

KEY WORDS: Medical Education, Computers, Teaching Aids, Information Technology, Faculty Development

\section{INTRODUCTION}

A teaching aid is something which makes teaching easier for the teacher and makes learning more effective and enjoyable for the student. More and more technological advances offer new paradigms for training, allowing novel forms of teaching and learning to be devised. Providing latest computer technology, good facilities and training for teachers to use computer in classroom is not sufficient. ${ }^{1-3}$ Many factors need to be examined in order to ensure that teachers use computer technology effectively. There have been some attempts to evaluate the use of computers in medical education, often in terms of measuring short term knowledge gain. ${ }^{4-6}$ in many cases, computers have been shown to improve student learning in this area. ${ }^{7-10}$

The success of any new educational program depends strongly on teachers support and involvement. With the advancement in information and communica- tion technologies, an increased application of new technologies in education leading to the development of new computer teaching aids is observed. ${ }^{11-13}$ but to what extent these teaching aids have been utilised by the teachers specially the senior faculties needs to be assessed. There is a need to assess the scope of newer form of teaching aids in improving undergraduate medical teaching and identify the barriers to its use. The study plans to assess the knowledge, attitude and practice of newer form of teaching aids and identify the barriers to use in the day to day teaching of medical students by faculty members of a newly established medical college.

\section{MATERIALS AND METHODS}

The study was a Cross sectional study using mixed quantitative and qualitative method conducted among faculty members of Jawaharlal Nehru Institute of Medical Sciences, (JNIMS) Imphal during the month of September 2014 to February 2015.
Cite this article : Rajkumari B. Barriers in using computer related teaching aids among faculty members in a newly established medical college - a Cross Sectional Study. Int J Med. Public Health. 2016;6(4):170-4. 
JNIMS is a newly established medical college under the State government which is just in its fifth year of inception. The study population includes all faculty members in the institute right from Assistant Professors to Professors. Refusals to participate and those not available on three attempts to contact where excluded from the study.

Sample size and sampling: Sample size was universal coverage of all faculties.

For the quantitative component a semi-structured interview schedule consisting of respondents characteristics, questions relating to knowledge about computer use, use of LCD projector in lecture class, knowledge and efficiency of preparation of power-point presentations, use of videos/ clippings for teaching students, methods of teaching and teaching aids commonly employed in the institute, most preferred methods of teaching, most preferred teaching aids, ease and difficulty level in using various methods etc. All eligible faculty members consenting to participate were interviewed using the interview schedule.

Qualitative component consist of In-depth interviews with faculty members who are not using or having difficulty with using newer from of teaching aids to identify barriers and factors inhibiting use with the help of an interview guide.

\section{Operational definition}

In this study the newer technology in teaching includes the use of computers, LCD projectors, video clippings, ability to prepare powerpoint slides and its use while taking theory lecture classes by the faculties. Using a Likert scale score, all responses for the quantitative component were graded and scores were summated across for knowledge related group of questions. Respondents scoring above $75^{\text {th }}$ percentile were graded as possessing adequate knowledge of computer related teaching aids, those scoring between $25^{\text {th }}$ to $75^{\text {th }}$ percentile as average and those scoring below $25^{\text {th }}$ percentile as having poor knowledge of computer related teaching aids.

\section{Statistical analysis}

Collected data was entered in Ms Excel spread sheet and transferred to IBM SPSS version 22 for analysis. Descriptive statistics were generated using percentages, percentile, mean and standard deviation. Analytical statistics like chi-square test were performed using selected variables to look for association A p-value of $<0.05$ was taken as significant. Transcription and translation of In-depth interviews were done and analysed using word processor software.

\section{Ethical issues}

Approval from the Institutional Ethics Committee was obtained. Informed consent was obtained from all participants before the interview. All identifiers were removed and strict confidentiality was maintained.

\section{RESULTS}

Out of a total 102 faculty, $88(86.2 \%)$ responded. Majority of the nonresponders, 11 (78.5\%) were from the clinical departments, 2 (14.2\%) were from Para-clinical and 1 (7.1\%) from pre-clinical department. Table 1 shows the background characteristics of the respondents. Almost one fourth 23 (26.1\%) of faculty were above 65 years of age and 20 (22.4\%) faculty had teaching experience of more than 30 years.

Table 2 shows the knowledge about newer teaching aids and its practice among the faculties. Among 12 (13.6\%) faculties who have no knowledge of computers most common reasons for not knowing was 'age factor' $7(55.8 \%)$, one fourth of them $3(25 \%)$ said they do not get the time to learn computers and $2(16.6 \%)$ stated as 'having no interest to learn' as the reason for not knowing. Majority of respondents learned computers through self-learning 41 (53.6), around 30 (39.4) of them learned from relatives and family and only 17 (22.4) took some formal computer course.

More than half 53 (60.2\%) of the respondents have undergone the 3 days basic training course in Medical Education Technology.

Faculties of the rank of Assistant and Associate Professors show a significantly higher knowledge score of newer teaching aids as compared to Professors. A significantly higher proportion of faculties who have undergone the 3 days Basic training in MET have higher score of Knowledge of newer teaching aids as compared to those who are yet to receive the basic training course. Table 3 .

For the Qualitative component in-depth interview of a 68 year old professor expresses that "Most professors are employed after retirement at 65 years at JNIMS, the medical teachers training workshop conducted by Banaras Hindu University was before the advent of computers in Imphal, and we are more use to board and marker". Professor 67 year stated that "The less experienced teacher who does not have much oratory skill and teaching talent depend heavily on computer slides, if machine or computer fails or if light goes off the class is cancelled". Another 66 year Professor put across that "Newer advance teaching learning technologies must be utilised properly in addition to age old time tested teaching learning methodology and not a complete replacement" and that "Older generation thinks old is gold and are more habituated to old teaching methods, preparing power-point is time consuming". All faculties agreed that basic training on Medical Education Technology be made compulsory and a faculty development program which includes basic training on computer use should be held regularly. Majority of the senior faculty opined that they do not find time to learn how to use a computer. Lack of interest in learning new things and feels too old to learn new technology were some of the most common reasons cited by the faculties who were not using the computer related newer teaching aids.

\section{DISCUSSION}

The study though one of the first kind related to medical education in the institution attempts to highlight the knowledge, attitudes and barriers towards use of computer related newer teachings aids among different levels of faculties in this newly established medical college in North-East of India. The study revealed that most of the senior ranked faculty lacked adequate knowledge of computer related newer teaching aids and shows preference to older methods. Lack of interest and not having enough time to learn were some of the major reason. As the Medical Council of India 'Teacher's Eligibility Guidelines 1998 for establishing medical colleges necessitates the employment of faculties with specified years of teaching experience along with definite requirements to be appointed to various levels teaching post in a medical college, the latest amendment of which under clause $1 \mathrm{~A}$ states that the maximum age limit up to which a teacher can be granted/appointed or re-employed as 70 years. ${ }^{14}$ Most faculties, especially of the post of professors in the institute were re-employed after retirement at 65 years of age from some other medical college. The study's findings also revealed that it was mostly the senior level faculty (53.8\%) who were having poor knowledge of computer use.

There is a recognized need for advancing the field of medical education as well as to bring in current trends and practices into it. However, there are limited opportunities for faculty in India to advance in the field of medical education. The Medical Council of India's guidelines on medical education have made training in the 3 days basic course workshop in Medical education Technologies compulsory for all faculties. ${ }^{15}$ The MCI basic course workshop in Medical Education Technologies require faculty to attain a certain level of expertise in medical education for quality assurance of the basic courses. The basic course workshop can be a platform for 
Table 1: Showing background characteristics of the respondents $(\mathrm{N}=\mathbf{8 8})$

\begin{tabular}{ccc}
\hline Variable & Categories & Number (\%) \\
\hline Age Group (Yr) & $31-40$ & $17(19.3)$ \\
Gender & $41-50$ & $23(26.1)$ \\
& $51-60$ & $22(24.0)$ \\
Department & $61-70$ & $26(29.5)$ \\
& Male & $55(62.5)$ \\
Designation & Female & $33(37.5)$ \\
& Pre-clinical & $13(14.8)$ \\
& Para clinical & $17(19.3)$ \\
Qualification & Clinical & $58(65.9)$ \\
& Assistant Professor & $60(68.2)$ \\
& Associate Professor & $2(2.3)$ \\
& Professor & $26(29.5)$ \\
Years of teaching experience (Yr) & MD/MS/MDS/Msc & $82(93.1)$ \\
& DM/MCH/PHD & $6(1.1)$ \\
& $0-10$ & $61(69.3)$ \\
& $11-20$ & $3(3.4)$ \\
& $21-30$ & $4(4.5)$ \\
& $31-40$ & $19(21.3)$ \\
& $>40$ & $1.1)$ \\
\hline
\end{tabular}

Table 2: Knowledge, attitude and practice of Newer Aids among the respondents

\begin{tabular}{|c|c|c|}
\hline Variable & Categories & Responses, N (\%) \\
\hline \multirow[t]{3}{*}{ Have basic knowledge of computer } & Yes & $76(86.4)$ \\
\hline & No & $12(13.6)$ \\
\hline & Total & $88(100)$ \\
\hline \multirow{9}{*}{$\begin{array}{l}\text { How often do you use computer in theory/lecture } \\
\text { class }\end{array}$} & Yes & $78(88.6)$ \\
\hline & No & $10(11.4)$ \\
\hline & Always & $44(50.0)$ \\
\hline & Most of the time & $26(29.5)$ \\
\hline & Sometimes & $7(8.0)$ \\
\hline & Rarely use & $1(1.1)$ \\
\hline & Never use & $10(11.4)$ \\
\hline & LCD/DLP projector & $24(27.3)$ \\
\hline & LCD/OHP/White board & $15(17.4)$ \\
\hline \multirow[t]{3}{*}{ Which aid you commonly use } & LCD/White board & $28(31.8)$ \\
\hline & OHP/slide projector & $9(10.2)$ \\
\hline & White board/notes & $12(13.6)$ \\
\hline \multirow[t]{4}{*}{ Know how to prepare power-point slides } & Yes & $74(84.1)$ \\
\hline & No & $14(15.9)$ \\
\hline & Very efficient & $13(14.8)$ \\
\hline & Efficient & $23(26.1)$ \\
\hline \multirow[t]{3}{*}{ If yes, How efficient } & Somewhat efficient & $31(35.2)$ \\
\hline & Not so efficient & $9(10.2)$ \\
\hline & Inefficient & $12(13.6)$ \\
\hline \multirow{3}{*}{$\begin{array}{l}\text { Take help/assistance in preparing power-point } \\
\text { presentations }\end{array}$} & Yes & $33(37.5)$ \\
\hline & No & $50(56.8)$ \\
\hline & Not applicable & $5(5.7)$ \\
\hline
\end{tabular}

Continued... 
Table 2: Knowledge, attitude and practice of Newer Aids among the respondents

\begin{tabular}{|c|c|c|}
\hline Variable & Categories & Responses, N (\%) \\
\hline \multirow{5}{*}{$\begin{array}{c}\text { Who helps/assist you in making power-point } \\
\text { presentations }(\mathrm{N}=33)\end{array}$} & Family members & $15(45.5)$ \\
\hline & Junior faculty & $10(30.3)$ \\
\hline & Colleagues/friends & $8(24.2)$ \\
\hline & $1-4$ & $5(5.7)$ \\
\hline & $5-7$ & $55(62.5)$ \\
\hline \multirow{3}{*}{$\begin{array}{l}\text { How many Lines in a power-point slide } \\
\qquad(\mathrm{N}=88)\end{array}$} & $8-10$ & $15(17.0)$ \\
\hline & $>10$ & $1(1.1)$ \\
\hline & Don’t know & $12(13.6)$ \\
\hline How many words per line & $1-4$ & $8(9.1)$ \\
\hline \multirow[t]{4}{*}{$(\mathrm{N}=88)$} & $5-7$ & $43(48.9)$ \\
\hline & $8-10$ & $23(26.1)$ \\
\hline & $>10$ & $2(2.3)$ \\
\hline & Don’t know & $12(13.6)$ \\
\hline Knowledge of computer is important for UG teaching & Strongly disagree & $0(0)$ \\
\hline \multirow[t]{5}{*}{$(\mathrm{N}=88)$} & Disagree & $1(1.1)$ \\
\hline & Neutral & $1(1.1)$ \\
\hline & Agree & $37(42.0)$ \\
\hline & Strongly agree & $49(55.7)$ \\
\hline & Strongly disagree & $0(0)$ \\
\hline \multirow{4}{*}{$\begin{array}{l}\text { Use of newer teaching aids will increase students } \\
\text { understanding } \\
\qquad(\mathrm{N}=88)\end{array}$} & Disagree & $0(0)$ \\
\hline & Neutral & $6(6.8)$ \\
\hline & Agree & $39(44.3)$ \\
\hline & Strongly agree & $43(48.9)$ \\
\hline \multirow{2}{*}{$\begin{array}{l}\text { How often you use video shows/clippings during } \\
\text { lecture class }\end{array}$} & Never & $24(27.3)$ \\
\hline & Rarely & $17(19.3)$ \\
\hline \multirow[t]{3}{*}{$(\mathrm{N}=\mathbf{8 8})$} & Sometimes & $39(44.3)$ \\
\hline & Most of the time & $6(6.8)$ \\
\hline & Always & $2(2.3)$ \\
\hline \multirow{2}{*}{$\begin{array}{c}\text { Know name of any software package for teaching } \\
\text { related to your specially }\end{array}$} & Yes & $18(20.5)$ \\
\hline & No & $70(79.5)$ \\
\hline \multirow{2}{*}{$\begin{array}{l}\text { Ever use such software in teaching Undergraduates } \\
\qquad(\mathrm{N}=18)\end{array}$} & Yes & $7(38.9)$ \\
\hline & No & $11(61.1)$ \\
\hline \multirow{2}{*}{$\begin{array}{l}\text { Undergone } 3 \text { days basic training course in MET } \\
\qquad(\mathrm{N}=88)\end{array}$} & Yes & $53(60.2)$ \\
\hline & No & $35(39.8)$ \\
\hline
\end{tabular}

Table 3: Comparison of knowledge scores of faculties with selected variables

\begin{tabular}{|c|c|c|c|c|c|}
\hline \multicolumn{2}{|l|}{ Variable } & \multicolumn{3}{|c|}{ Knowledge scores, N(\%) } & \multirow[t]{3}{*}{ p-value } \\
\hline & & Poor & Average & Adequate & \\
\hline & & $<25^{\text {th }}$ percentile & $25^{\text {th }}-75^{\text {th }}$ percentile & $>75^{\text {th }}$ percentile & \\
\hline \multirow[t]{2}{*}{ Gender } & Male & $14(25.5)$ & $11(20)$. & $30(54.5)$ & 0.849 \\
\hline & Female & $7(21.2)$ & $8(24.2)$ & $18(54.5)$ & \\
\hline \multirow[t]{2}{*}{ Department } & Pre\&Paraclinical & $5(16.7)$ & $8(26.7)$ & $17(56.7)$ & 0.456 \\
\hline & Clinical & $16(27.6)$ & $11(19.0)$ & $31(53.4)$ & \\
\hline \multirow[t]{2}{*}{ Designation } & AP \& Assoc & $7(11.3)$ & $13(21.0)$ & $42(67.7)$ & 0.001 \\
\hline & Professor & $14(53.8)$ & $6(23.1)$ & $6(23.1)$ & \\
\hline \multirow[t]{2}{*}{ Years of teaching exp } & $\leq 12 \mathrm{yr}$ & $6(9.8)$ & $13(21.3)$ & $42(68.9)$ & 0.001 \\
\hline & $<12 \mathrm{yr}$ & $15(55.6)$ & $6(22.2)$ & $6(22.2)$ & \\
\hline \multirow[t]{2}{*}{ Undergone 3 days basic training in MET } & Yes & $4(7.5)$ & $13(24.5)$ & $36(67.9)$ & \\
\hline & No & $17(48.6)$ & $6(17.1)$ & $12(34.3)$ & 0.01 \\
\hline
\end{tabular}


Rajkumari B: Barriers in using computer related teaching aids

reorienting faculties to different new technologies and aids which can be used to improve undergraduate medical teaching. Although majority of the senior level faculty (76.9\%) lack adequate knowledge of computer almost all faculties (98\%) agrees or strongly agrees to the statement that knowledge of computer is important for undergraduate teaching and 93\% agrees that use of newer teaching aids will improve student's understanding. The study also shows that faculties who have undergone the 3 days basic course in MET have significantly higher knowledge of computer related teaching aids as compared to faculties who have not. As stated by McManus IC 'Medicine in three decades will have changed so as to be almost unrecognisable, and education will follow it'. The major qualitative change will be in information technology. ${ }^{16,17}$

The study shows statistically significant differences of higher knowledge of computer among lower and middle level faculty as compared to senior faculties like professors. Another main objective of the study was to assess the barriers or factors limiting the use. The advent of computers and use of information technologies in the state started only around late nineties and many of the professors showed disinterest in learning. Another limiting factor was time as some of them stated that they could not fine time to learn computers due to their busy schedule.

One limitation of this study was that we were not able to cover all the faculties in the institute and in depth interviews were conducted only with select faculties who were not using computers to identify barriers. A larger sample would have permitted a stronger analysis but nevertheless the study was able to cover $86 \%$ of the study population and was able to identify some of the hurdles newly established medical colleges have to encounter.

\section{CONCLUSION}

Majority of the senior faculty were not familiar with computer related teaching aids though generally it was felt that use of newer form of teaching will improve students understanding. Time and lack of interest being the major limiting factor for not using them. Introducing faculty development programs which incorporates a short course on use of computers and other computer related teaching aids may be helpful in overall teaching and progress in medical teaching.

\section{ACKNOWLEDGEMENT}

The author would like to thank Prof PV Vijayaraghavan and all the members of MEU at MCI- SRMC Nodal Center, Chennai for MCI Fellowship in Medical Education (FIME).

\section{CONFLICT OF INTEREST}

None

\section{Funding: Nil}

\section{ABBREVIATION USED}

LCD: Liquid Crystal Display; MET: Medical Education Technology; JNIMS: Jawaharlal Nehru Institute of Medical Sciences.

\section{REFERENCES}

1. Brazdeikis $V$, Masaitis M. Teaching Aids in Teaching and Learning Environments of Lithuanian Schools. Socialiniaimokslai. 2012;76(2):74-83. http://dx.doi. org/10.5755/j01.ss.76.2.1964.

2. Stensass SS. Multimedia: why aren't we using more of it?. Teach Learn Med. 1995;7:130-2

3. Polyakov A, Palmer E, Devitt PG, Coventry BJ. Clinicians and computers: friends or foes. Teach Learn Med. 2000;12:91-5. http://dx.doi.org/10.1207/ S15328015TLM1202_6; PMid:11228684.

4. Anderson JG, Jay SJ Schweer HM, Anderson MM. Why doctors don't use computers: some empirical findings. J Royal Soc of Med. 1986;79(97-109):142-4.

5. Devitt P, Palmer E. Computers in medical education - 1: Evaluation of a problemoriented learning package. Aust N Z J Surg. 1998;68(4):284-7. http://dx.doi. org/10.1111/j.1445-2197.1998.tb02084.x; PMid:9572340.

6. Devitt $P$, Palmer E. The role of computers in medical education. University of Adelaide, South Australia. Rev Cubana Educ Med Super. 2001;15:76-84

7. South M, Nolan T. Computer-assisted instruction in Australian medical schools. Med J Aust. 1993;159(3):175-6. ; PMid:8336617.

8. Jenkins S, Goel R, Morrell DS. Computer-assisted instruction versus traditional lecture for medical student teaching of dermatology morphology: a randomized control trial. J Am Acad Dermatol. 2008;59(2):255-9. http://dx.doi.org/10.1016/j. jaad.2008.04.026; PMid:18499299

9. Rogers DA, Regehr G, Yen KA, Howdieshell TR. Computer-assisted learning versus a lecture and feedback seminar for teaching a basic surgical skill. Am J Surg. 1998;175(6):508-10. http://dx.doi.org/10.1016/S0002-9610(98)00087-7.

10. Davis J, Crabb S, Rogers E, Zamora J, Khan K. Computer-based teaching is as good as face to face lecture-based teaching of evidence based medicine: a randomized controlled trial. Med Teach. 2008;30(3):302-7. http://dx.doi. org/10.1080/01421590701784349; PMid:18484458.

11. Cork RD, Detmer, Friedman CP. Development and Initial Validation of an Instrument to Measure Physicians' Use of, Knowledge about, and Attitudes Toward Computers. JAMIA. 1998;5(2):164-76. http://dx.doi.org/10.1136/ jamia.1998.0050164.

12. Al Maghraby MA Alshami AM Learning style and teaching method preferences of Saudi students of physical therapy. J Fam Community Med. 2013;20(3):192-7. http://dx.doi.org/10.4103/2230-8229.122017; PMid:24672278 PMCid:PMC3957174

13. Shaker HA, Farooq MU. Computer literacy of physicians among the hospitals of Makkah region. J Fam Community Med. 2013;20(3):173-8. http://dx.doi. org/10.4103/2230-8229.121998; PMid:24672275 PMCid:PMC3957171.

14. MEDICAL COUNCIL OF INDIA. Minimum Qualifications forTeachers inMedical Institutions Regulations, 1998[AMENDED UPTO MAY 2015; cited 2015 Dec 22 ] available at http://www.mciindia.org/Rules-and-Regulation/TEQ-REGULATIONS-16.05.15.pdf.

15. MEDICAL COUNCIL OF INDIA. Faculty Development Program. [cited 2016 Jan 5] Available at http://www.mciindia.org/fdp/Programme_Detail.pdf.

16. McManus IC How will medical education change?. The Lancet. 1991;337(8756):1519-21. http://dx.doi.org/10.1016/0140-6736(91)93205-N.

17. Parry KM. The curriculum for the year 2000. Med Educ. 1989;23:301-04. http:// dx.doi.org/10.1111/j.1365-2923.1989.tb01549.x. 